\title{
The anterior pituitary and reproduction in bats
}

\author{
B. A. Richardson \\ Department of Anatomy, College of Medicine, University of Arizona, Tucson, \\ Arizona 85724, U.S.A.
}

\begin{abstract}
Summary. This contribution is a review of investigations on the role(s) of the anterior pituitary in chiropteran reproduction. Information on this subject has come mainly from histological studies of cytological changes during the annual cycle and mostly from hibernating temperate-zone species. Although direct evidence is unavailable, it appears that variations in the temporal synchronization of specific endocrine functions of the pars distalis are involved, at least in part, in several of the numerous reproductive specializations found in bats. Mention is also made of recent studies on the anterior pituitary of Macrotus californicus and its possible involvement in delayed development.
\end{abstract}

\section{Introduction}

Reproduction in Chiroptera is of special interest due to the numerous adaptive specializations exhibited by this diverse and successful group of mammals. These specializations were discussed by the previous participants of this symposium and have been reviewed in part elsewhere (Wimsatt, 1960, 1969). Although the anterior pituitary undoubtedly plays a major role in regulating the sexual cycles of bats, there is little information about its structural or functional correlates to reproductive function, in contrast to the abundance of research on the reproductive histophysiology of the adenohypophyses of other vertebrates (Herlant, 1964b; Purves, 1966; Baker, 1974).

The purpose of this paper is to review the cytophysiology of the chiropteran anterior pituitary and its involvement in the reproductive biology of both males and females in hibernating and nonhibernating species. My own recent studies on the pars distalis of the California leaf-nosed bat, Macrotus californicus, and its possible role in delayed development are also discussed.

\section{Cell nomenclature of the bat anterior pituitary}

Before the advent of techniques for direct intracellular localization of hormones, two nonfunctional nomenclature systems were utilized for the cell types of the anterior pituitary. Romeis (1940) employed Greek letters, based on cell morphology and tinctorial properties. However, subsequent workers did not always use the same letter for a particular cell type, and this led to confusion (Purves, 1966; Baker, 1974). The second system was derived from the colour of the cytoplasm after specific staining procedures (orangeophil, etc.); it also brought confusion, since colour affinities and reactions are subject to numerous technical variables. Furthermore, tinctorial properties of hypophysial cells show interspecies variability (Herlant, 1964b; Purves, 1966; Baker, 1974).

To avoid confusion I shall employ the functional nomenclature recommended by the International Committee for Nomenclature of the Adenohypophysis (Van Oordt, 1965). It must be realized, however, that this nomenclature reflects the one-cell :one-hormone dogma which no 
longer appears applicable. Recent immunohistochemical studies on the mammalian adenohypophysis localize more than one hormone within the same cell (Nakane, 1970; Herbert, 1975, 1976; Moriarty, 1975, 1976; Moriarty \& Garner, 1977; El Etreby \& Fath El Bab, 1977). In a slight deviation from the recommended nomenclature, LH (luteinizing hormone) will be used for both sexes instead of ICSH (interstitial cell stimulating hormone), since the former is prevalent in the literature.

\section{Cytology of the bat anterior pituitary}

Early cytological investigations on the bat hypophysis suggested that the various cell forms represented a series of developmental stages of a single type of secretory cell (Guthrie, 1935; Sawyer, 1936). Subsequent studies, however, showed that the anterior pituitary consists of several distinct cell types as in other mammals. A brief discussion of these cells follows.

\section{Somatotrophic cell (STH cell)}

Somatotrophic cells are considered the most abundant type in both sexes (Herlant, 1953, 1956; Patil, 1974). They are usually ovoid or round, occur in clusters and contain homogeneous orangeophilic granules uniformly distributed within the cell. Though STH cells are found throughout the pars distalis, they are prominent in the anterolateral region in Hipposideros (Patil, 1974) and the posterolateral region in Myotis (Herlant, 1956).

Ultrastructural criteria for identification of adenohypophysial cell types include size, shape and electron opacity of the secretory granules and morphology of intracellular organelles. STH secretory granules in the bat are dense, membrane-enclosed and from 350 to $400 \mathrm{~nm}$ in diameter (Herlant, 1962, 1963; Azzali, 1971). The mitochondria have spaced cristae, and the Golgi apparatus consists of dilated vesicles (Herlant, 1963).

\section{Prolactin cell (lactotrophic or LTH cell)}

Prolactin cells differ in tinctorial properties, morphology and cytology from somatotrophs. In general, they are larger (Herlant, 1953, 1956; Patil, 1974), show affinity for erythrosin, azocarmine and carmoisine L (Herlant, 1953, 1956; Azzali, 1971; Richardson, 1978), and usually form palisades with their long axes polarized toward a capillary (Herlant, 1953, 1956). The distribution and number of prolactin cells show seasonal variation (Herlant, 1953, 1956).

Electron microscopic observations of LTH secretory granules vary with the species. In Myotis myotis Herlant (1963) reported the granules to range from 170 to $250 \mathrm{~nm}$, whereas in Vesperugo savi and V. piccolo (Azzali, 1971) they are 700-800 nm. In lactating M. myotis the Golgi is extensive and shows granule formation (Herlant, 1964a, 1968).

\section{Thyrotrophic cell (TSH cell)}

Thyrotrophic cells are small, polygonal and scattered throughout the anterior pituitary (Herlant, 1953, 1956; Patil, 1974). Microscopically, Patil showed that the cytoplasmic granules often occur as aggregates in Hipposideros fulvus, but are evenly distributed in $H$. ator and $H$. spioris. The cytoplasm stains with PAS, aldehyde fuchsin and aniline blue (Siegel, 1955; Herlant, 1956; Azzali, 1971; Patil, 1974). Both Herlant and Patil reported little seasonal change in TSH cells. Siegel (1955) studied male Myotis lucifugus under different experimentally induced physiological states and found alterations in the cells classified as thyrotrophs. His observations have been confirmed ultrastructurally by Kobayashi (1966) and Kobayashi \& Herman (1966) in hibernating and 'normal' $M$. lucifugus and $M$. velifer. 
TSH secretory granules appear to be the smallest of all cell types. Kobayashi (1966) found those of $M$. lucifugus and $M$. velifer to be similar to those in the rat, where they range from 100 to $150 \mathrm{~nm}$ (Kurosumi, 1968). In $V$. savi and $V$. piccolo they are $110 \mathrm{~nm}$ in diameter (Azzali, 1971). Other ultrastructural characteristics include vesiculated cisternae of the rough endoplasmic reticulum and a paucity of free ribosomes (Herlant, 1963; Kobayashi \& Herman, 1966).

\section{Gonadotrophic cells}

The gonadotrophic cells are large, oval or round; they form palisades next to capillaries (Herlant, 1953, 1956; Patil, 1974). Distribution appears to be a function of species, age, sex and state of reproduction (Herlant, 1953, 1956; Siegel, 1955; Patil, 1974). The cytoplasm stains with PAS, methylene blue, alcian blue and aniline blue (Herlant, 1953, 1956; Siegel, 1955; Azzali, 1971; Patil, 1974).

Ultrastructurally, gonadotrophs contain dense secretory granules ranging in diameter from 150 to more than $300 \mathrm{~nm}$ (Herlant, 1963, 1964a, 1968; Azzali, 1971). Herlant noted that the organelles seem to vary with the reproductive state of the animal.

Based on cyclic alterations in number, tinctorial properties and ultrastructure as correlated with the reproductive and activity cycles, gonadotrophs have been divided into two functional groups: follicle-stimulating hormone (FSH) cells and $\mathrm{LH}$ cells (see above). At the light microscopic level this division has been accomplished in M. myotis (Herlant, 1956), V. savi and $V$. piccolo (Azzali, 1971) and H. fulvus (Patil, 1974). In addition, Azzali (1971) examined the effects of castration on gonadotrophs in $V$. savi and $V$. piccolo.

The most detailed study of gonadotrophs has been of female M. myotis (Herlant, 1956), a hibernating vespertilionid which shows delayed ovulation. The putative FSH cells are large, form honogeneous cords and lie mainly in the anteromedial region of the gland. The cytoplasm contains finely granulated material which stains sky blue with the Cleveland-Wolfe or Heidenhain's trichrome techniques and violet with PAS-orange G. These cells appear to hypertrophy with onset of the autumnal rut and hiberation, and they remain 'active' until spring arousal and ovulation, when they involute. Putative LH cells are smaller, occupy the centre of cell cords and lie primarily in the posterior regions. When active, their cytoplasm appears homogeneous, due to the abundance of granules; it stains violet with the Cleveland-Wolfe technique and brick red with PAS-orange G. These cells hypertrophy during gestation and involute after parturition. Azzali (1971) observed a similar dichotomy of gonadotrophs in the hibernators $V$. savi and $V$. piccolo.

In contrast to M. myotis, H. fulvus is a nonhibernator (Patil, 1974). Copulation occurs in November, followed by ovulation and fertilization. The corpus luteum reaches maximal development at implantation, after which it involutes rapidly and disappears by mid-pregnancy. Parturition then occurs at the beginning of May. FSH cells in H. fulvus are large and oval; they predominate in the lateral posterior region of the adenohypophysis. The cytoplasm is often vacuolated and contains fine or diffused granules which stain blue or purple with PASmethylene blue-orange G. From October to mid-November (oestrus) these cells are hypertrophied and intensely chromophilic. After ovulation (during early pregnancy) involution occurs, which essentially lasts until the subsequent pro-oestrus. $\mathrm{LH}$ cells in $H$. fulvus are smaller and rounded or irregular in shape; they are distributed uniformly throughout the gland. The granules are coarse and amphophilic; they stain red with PAS-methylene blue-orange G. LH cells are not distinguishable until early pregnancy (March). In later pregnancy and lactation, they hypertrophy and appear to increase in number, followed by a regression after lactation ceases.

Herlant $(1962,1963,1964 a, 1968)$ described the ultrastructural characteristics of FSH and LH cells during the reproductive cycle of female $M$. myotis. Although he did not report the size 
of the FSH secretory granules, he stated that they offered a distinct image described as an "éclatement" ('bursting'). LH cells, in contrast, exhibit two different morphologies. One type contains homogeneous granules with a diameter of $180 \mathrm{~nm}$ and others often exceeding $300 \mathrm{~nm}$. The endoplasmic reticulum in both types of cells consists of canaliculi parallel to the plasma membrane or the nuclear envelope, while the mitochondria contain more distinct cristae than in FSH cells.

Electron microscopic data on cytological alterations of gonadotrophs during the reproductive cycle of $M$. myotis agree with the light microscopic findings. In autumn (when copulation occurs) and throughout hibernation, the FSH cells contain dense granules with few 'bursting' figures. In addition, the Golgi apparatus is well developed and often contains immature secretory granules. After ovulation and fertilization, the density of the granules decreases as they dilate and the Golgi breaks down. The $\mathrm{LH}$ cells increase in activity during spring ovulation; the Golgi hypertrophies and contains numerous immature granules. Granules increase in number during gestation up to parturition, when a general involution of these cells occurs; cell volume decreases and the Golgi regresses.

Azzali (1971) reported for $V$. savi and $V$. piccolo that the secretory granules in both gonadotrophs are the same diameter $(210 \mathrm{~nm})$. He indicated, however, that their cytology varies with the reproductive state.

Although the one-cell : one-hormone theory is generally accepted for most adenohypophysial hormones, there is still controversy on the cellular site for synthesis and secretion of FSH and LH. The advent of immunohistochemical techniques for localization of intracellular material and the availability of purified antisera to pituitary hormones have resulted in the detection of both gonadotrophins in the same cells (Nakane, 1970; Herbert, 1975, 1976; Moriarty, 1975, 1976; El Etreby \& Fath El Bab, 1977). My own preliminary immunocytochemical observations suggest that at least three populations of gonadotrophs exist in the hypophysis of Macrotus californicus: those which contain both LH and FSH (Pl.1, Figs 1a and 1b), and those that contain either LH or FSH. Therefore, evidence for separate FSH and LH cells in bats should be viewed as tentative.

\section{Corticotrophic cell (ACTH cell)}

Very little information is available on corticotrophs of bats. In M. myotis, Herlant (1956) grouped these cells with the classical acidophils at the light microscopic level. Azzali (1971) described ACTH cells in $V$. savi and $V$. piccolo as erythrosinophilic and having secretory granules $400 \mathrm{~nm}$ in diameter.

\section{Follicular cell}

Electron microscopy demonstrates a cell type devoid of secretory granules in bat pituitaries. In $M$. lucifugus and M. velifer Kobayashi \& Herman (1966) found these so-called follicular cells to contain numerous vesicles, desmosomes and an occasional multivesicular body; these cells were also frequently found bordering extracellular spaces filled with a colloid-like substance. In $V$. savi and V. piccolo, Azzali (1971) saw follicular cells organized into thyroid-like follicles and bearing cilia with a $9+0$ fibrillar pattern. It is generally felt that the follicular cells of the pars distalis serve as a supporting stroma for parenchymal cells (Baker, 1974).

\section{The bat anterior pituitary and reproduction}

Information on the role(s) of the chiropteran anterior pituitary in reproduction is based mainly upon inferential data from staining methods and electron microscopy of cytological changes 
during the annual cycle. Most of this work concerns the female of hibernating temperate species, exploiting the marked adaptations found in the female reproductive physiology due to overlap of the annual periods of hibernation and reproduction (Wimsatt, 1969). It should not be assumed, however, that these adaptations necessarily result in qualitative cytophysiological differences in the chiropteran adenohypophysis when compared to those of other mammalian groups. For example, FSH and LH are probably elaborated, secreted and functionally the same as in other mammals. Variations, if they occur, would probably be in the temporal synchronization of specific endocrine functions of the pars distalis (Wimsatt, 1969). The following discussion of the reproductive functions of the chiropteran adenohypophysis includes some preliminary observations of my own on the pars distalis of Macrotus californicus.

\section{Correlations in the male}

The most detailed cytophysiological study of male bats was by Siegel (1955) on $M$. lucifugus. While dividing the classical basophils into putative thyrotrophs and gonadotrophs, he could not distinguish between FSH and LH cells. Moreover, since animals were collected during a restricted period of the reproductive cycle, he could not clarify the role of the anterior pituitary.

Two others authors have touched upon the cytology of the anterior pituitary of male bats (Epomophorus anurus and M. myotis: Herlant, 1953; V. savi and V. piccolo: Azzali, 1971) while Racey (1974) examined seasonal changes in pituitary weight in Nyctalus noctula. Again these studies provide little information as to the function of the anterior pituitary in bat reproduction.

Hypophysial control of testicular function in bats has been suggested by Herlant (1967). $M$. daubentoni and $M$. mystacinus were collected during hibernation, when the seminiferous tubules consist mainly of inactive Sertoli cells and occasional spermatogonia (mitotic divisions of these cells are rare at this time). Herlant examined the effects of exogenously administered FSH on the cytology of the tubules and on Sertoli cell fine structure. At the light microscopic level, an obvious proliferation of spermatogonia was seen. However, the Sertoli cells appeared identical to those in controls. When examined with the electron microscope after 5-7 days of treatment, the Sertoli cells acquired the characteristics of an actively secretory cell: hypertrophied Golgi, enhanced cytoplasmic vacuoles and microvesicles and well-developed mitochondria. After 10 days of treatment, the Sertoli cells appeared exhausted, while the spermatogonia continued to divide. It was also observed that spermatogenesis did not progress beyond the proliferative stage. Herlant concluded that the primary effect of FSH is on the Sertoli cell, while the increase in dividing spermatogonia is a secondary consequence.

The effects of FSH on bat Sertoli cells are similar to those reported in other mammals (Steinberger \& Steinberger, 1973). While there is still not general agreement on the specific roles of $\mathrm{LH}$ and FSH in spermatogenesis, it appears that initial stages are under the influence of $\mathrm{LH}$ (via androgens), whereas maturation of spermatids seems to require FSH.

\section{Correlations in the female}

Female hibernating bats exhibit several reproductive patterns which appear to be directly related to hibernation (Wimsatt, 1969). In almost all vespertilionids, the terminal maturation and ovulation of the definitive Graafian follicle (already markedly developed at the autumnal initiation of hibernation), is delayed until the following spring arousal. This process has been termed 'delayed ovulation'. Miniopterus schreibersii (and possibly $M$. australis) differs from other hibernating vespertilionids (see below). The situation in hibernating rhinolophids apparently differs from that in vespertilionids in that numerous Graafian follicles are present in the functional ovary during hibernation (recent observations by Ramakrishna \& Rao (1977) suggest the occurrence of delayed implantation in Rhinolophus rouxi). It is unclear whether or not the follicle destined to ovulate in the spring persists throughout hibernation. The anterior 
pituitary of rhinolophids has received little attention. Herlant (1953) has made some casual observations on the cytology of the pars distalis of Rhinolophus ferrumequinum and $R$. hipposideros.

It is established that gonadotrophins influence follicular growth (FSH) and ovulation (LH) in many mammals. It is reasonable to expect that these same substances have similar effects in bats. Wimsatt (1960) has suggested that delayed ovulation results in part from asynchronous secretion of FSH and LH. The extensive work of Herlant $(1953,1956,1963,1964 a, 1968)$ on the histophysiology and ultrastructure of the anterior pituitary of female $M$. myotis supports this hypothesis.

Herlant assumes a correlation between the seasonal alterations in the cytology of the pars distalis and the reproductive cycle of $M$. myotis. Since his findings were discussed above, it will suffice to mention that from tinctorial properties he was able to distinguish three basophils. One type undergoes little change throughout the reproductive cycle; he therefore concluded that these cells were thyrotrophs. The other two types undergo asynchronous periods of hypertrophy and involution corresponding to specific phases of the cycle. One cell, his "type II", becomes prevalent at the onset of hibernation and remains hypertrophied until spring, when it involutes after ovulation. Since the Graafian follicle is maintained during hibernation, and because the cell granules were selectively extracted with trichloroacetic acid (see Barrnett, Ladman, McAllaster \& Siperstein, 1956), Herlant inferred that the "type II" basophil is responsible for elaboration and secretion of FSH. "Type I" basophils, on the other hand, hypertrophy around the time of ovulation and do not involute until after parturition. Since the corpus luteum also undergoes post-partum regression, these cells were presumed to secrete $\mathrm{LH}$. The cyclicity of these two cell types has been further substantiated ultrastructurally by Herlant (1962, 1963, 1964a, 1968), and Azzali (1971) appears to have observed similar cytological changes in $V$. savi and $V$. piccolo with the light and electron microscopes. These data imply that delayed ovulation may well result from insufficient quantities of $\mathrm{LH}$ and that the Graafian follicle is maintained by a tonic secretion of FSH.

It is of interest to comment on the cells that Herlant assumed to secrete prolactin. In $M$. myotis these cells show two peaks of activity; one coincides with ovulation, the other with parturition and lactation. The first peak suggests that prolactin may have a luteotrophic effect in this animal. Herlant (1968) reported (based on ultrastructural observations) that granules are extruded from the presumed prolactin-secreting cells during gestation, an interpretation which lends support for a luteotrophic effect of prolactin.

To elucidate the hormonal mechanisms in follicular growth, induction of ovulation and delayed ovulation, several studies on effects of premature arousal from hibernation and of exogenous administration of hypophysial extracts and gonadotrophins have been conducted on female hibernating vespertilionids (see Zondek, 1933; Guthrie \& Jeffers, 1938; Smith, 1951; Sluiter, Bels \& Van Oordt, 1952; Skreb, 1955; Wimsatt, 1960; Racey, 1976). In general, these studies showed that animals prematurely aroused during the second half of hibernation often ovulate, but that exogenous hormones were necessary (in addition to arousal) for ovulation to occur during the first half of this period. Although these data implicate the gonadotrophins in ovulation, and possibly in delayed ovulation, they are far from conclusive. As Racey (1976) has indicated, it is difficult to draw conclusions from these experiments, due to variations in the doses of hormones administered and in the physiological state of the animals. Moreover, many of these studies took place before modern purification procedures and it is possible that the hormone preparations contained other hormones or substances which may have caused or influenced the effects observed.

Miniopterus schreibersii differs from other hibernating vespertilionids in that the females enter hibernation already pregnant but implantation is delayed until the spring arousal (Peyre \& Herlant, 1963a, b). These authors have examined the putative FSH, LH and prolactin cells in female $M$. schreibersii at various times of the reproductive cycle. When ovulation and copulation 
occur (September), FSH cells are full of fine granulations while LH cells are only beginning to accumulate granules and prolactin cells are indistinguishable. During delayed implantation (from October to March), the FSH granules appear to decrease. LH cells are granulated, but seem to be inactive. At the end of hibernation (March), when implantation occurs, the prolactin cells show signs of differentiation. As embryogenesis proceeds (in May and June), the corpus luteum assumes an active appearance and LH cells become hypertrophied and full of granules. They remain so until the end of gestation. Prolactin cells also increase in size and granule content at this time, while FSH cells remain chromophilic and appear active. Since the presumed prolactin cells hypertrophy at the time of implantation and activation of the corpus luteum, Peyre \& Herlant (1963a, b) concluded that this hormone plays a role (directly or indirectly) in these two processes.

While Herlant (1953) has commented on the cytology of the pars distalis of the pteropodid Epomophorus anurus, the only definitive study to date on nonhibernating bats has been by Patil (1974), who worked on three species of Hipposideros. The emphasis of Patil's study was on $H$. fulvus fulvus, whose reproductive cycle was summarized above. During oestrus (from October to mid-November), there was hypertrophy of FSH cells. After ovulation and during early pregnancy, such cells became less prominent, but reappeared later in gestation. However, they did not regain the same level of hypertrophy until the subsequent pro-oestrus. LH and prolactin cells could not be distinguished until mid-gestation, when the corpus luteum disappeared. These cells then increased in size and number, and subsequently involuted at the termination of pregnancy and lactation. While it seems reasonable that FSH cells in Hipposideros are active during follicular growth, and that LTH cells appear at mid-pregnancy and hypertrophy after parturition, it is unclear why LH cells make an appearance only after the regression of the corpus luteum. The usual situation in mammals is for the corpus luteum to be maintained, at least in part, by LH (Moudgal, 1973). Perhaps LH is secreted as soon as it is elaborated. Consequently, stainable granules may not accumulate, thus giving LH cells an involuted appearance when they are actually active.

Ramaswami \& Anand Kumar (1966) observed the effects of a number of exogenous hormones, including the gonadotrophins and LTH, on the reproductive tracts of female Rhinopoma kinneari, a nonhibernating species. In females collected and treated during anoestrus, they were able to induce ovulation and corpus luteum formation with exogenous $\mathrm{LH}$ or human chorionic gonadotrophin (hCG), but not even a corpus luteum atreticum with exogenous LTH. They concluded that LTH is solely lactogenic, since they could initiate milk secretion with exogenous LTH.

Macrotus californicus is a nonhibernating monoestrous phyllostomatid bat that is indigenous to the southwestern United States. The female is of particular interest because of its unique reproductive biology (see Text-fig. 1) which has been described by Bradshaw $(1961,1962)$. Oestrus, insemination and fertilization occur in the autumn. After fertilization, development proceeds to implantation of the blastocyst as in most mammals. Thereafter, however, a $4-4 \frac{1}{2}$ month period of retarded embryonic growth ensues in which cells divide at a reduced rate with little, if any, cellular differentiation. Bradshaw (1961) termed this phenomenon "delayed development". 'Normal' development then begins in March and continues to parturition in June, followed by lactation.

Burns \& Wallace (1975) and Burns \& Easley (1977) have examined the endocrine role of the ovary of $M$. californicus in delayed development. They observed a correlation between circulating plasma levels of oestradiol-17 $\beta$ and progesterone and the cessation of delayed embryogenesis. The involvement of higher centres, such as the pituitary, has yet to be explored.

The study of Richardson (1978) on the pars distalis of the female $M$. californicus is designed to correlate seasonal alterations in the number and morphological features of prolactin and $\mathrm{LH}$ cells with events of the annual reproductive cycle, and thus to ascertain the role, if any, that this gland plays in delayed development. 


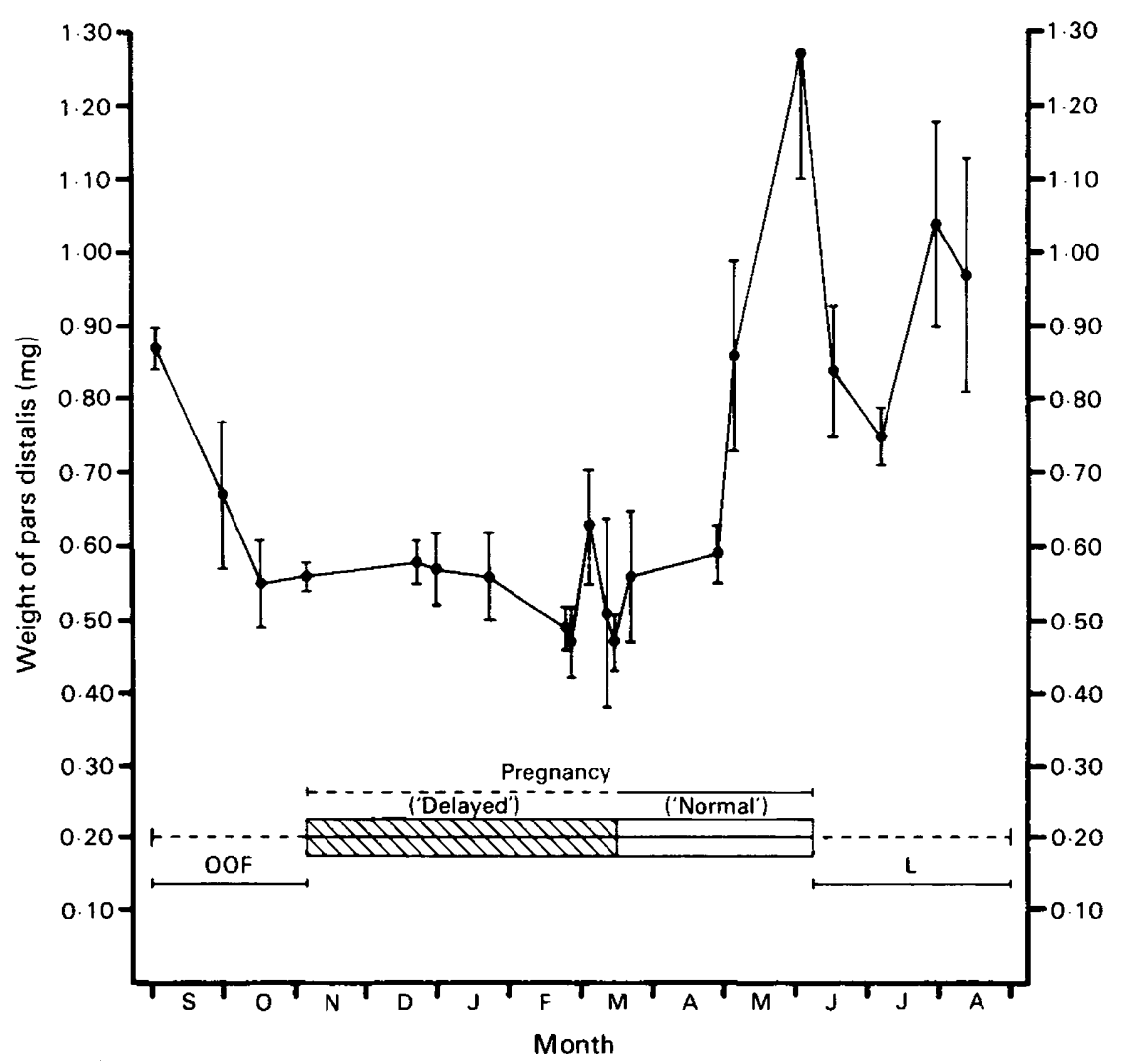

Text-fig. 1. Schematic representation of the female reproductive pattern of Macrotus californicus, and seasonal changes in the mean ( \pm s.e.m.) weight of the pars distalis of adult females. OOF $=$ oestrus, ovulation and fertilization; $\mathrm{L}=$ lactation.

Pituitary glands from female $M$. californicus were immersion-fixed in Bouin's or modified Bouin's fixatives, dehydrated and embedded in paraffin wax. Serial sections 3-4 $\mu \mathrm{m}$ thick were collected and mounted separately, such that 5 sections were affixed in sequence to 5 separate slides. This procedure permits comparison of 5 different staining techniques on adjacent sections. To demonstrate prolactin and LH cells, sections were stained for light microscopic immunocytochemistry with the unlabelled antibody peroxidase-antiperoxidase complex technique of Sternberger, Hardy, Cuculis \& Meyer (1970). Antisera against rat prolactin and the $\beta$ unit of rat LH were kindly provided by $\operatorname{Dr}$ A. F. Parlow (NIAMDD). The peroxidase-antiperoxidase complex was kindly supplied by Dr L. A. Sternberger. Appropriate specificity controls for staining and primary antisera were conducted for each antiserum.

Pituitaries collected in September, when lactation is near completion, showed a moderate number of immunoreactive prolactin cells scattered throughout the pars distalis, with a slight concentration in the lateral wings (Pl. 1, Fig. 2). These cells varied in form, and many appeared hypertrophied. In the same pituitary stained with anti-LH $\beta$, cells were again scattered throughout the gland, but a slight increase in density could be seen anteriorly (Pl. 1, Fig. 3). Immunoreactive LH cells appeared pleomorphic and similar in size to prolactin cells.

During early pregnancy (November) the pituitary was almost devoid of intensely staining immunoreactive prolactin cells, and the few cells that were present contained little cytoplasm. Cells stained with anti-LH $\beta$ were similar to those seen in September, except that their form had become more varied. 


\section{PLATE 1}

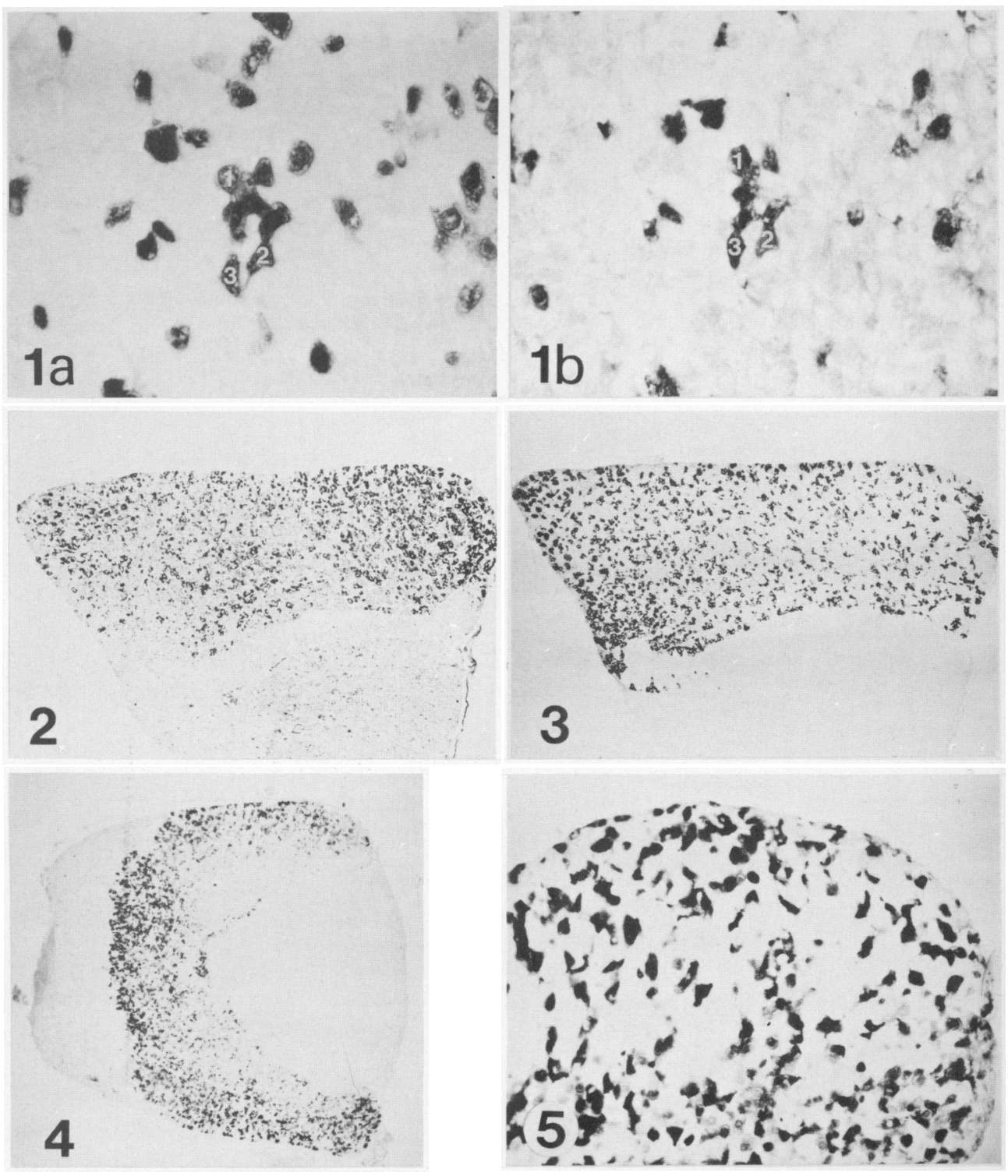

Figs $1 \mathrm{a}$ and $\mathbf{b}$. Immunocytochemical evidence that the same cells are stained with antisera to both LH $\beta$ and FSH $\beta$ in the pars distalis of a female Macrotus californicus. A few cells in each micrograph and labelled for comparison. $\times 440$. (a) A $4 \mu \mathrm{m}$ thick section stained with anti-rat $\mathrm{LH}$ $\beta$ serum. (b) Adjacent $4 \mu \mathrm{m}$ thick section stained with anti-rat FSH $\beta$ serum.

Fig. 2. Horizontal section of a pituitary gland from $M$. californicus collected in September immunostained with antiserum to rat prolactin $(\mathrm{rLTH}) . \times 72$.

Fig. 3. Horizontal section from the same pituitary as in Fig. 2 immunostained with anti-rLH $\beta$ serum. $\times 72$.

Fig. 4. Horizontal section of a pituitary gland from $M$. californicus collected in March immunostained with anti-rLTH serum. $\times 43$.

Fig. 5. Oblique sagittal section of the pars distalis from $M$. californicus collected in March immunostained with anti-rLH $\beta$ serum. $\times 180$. 


\section{PLATE 2}
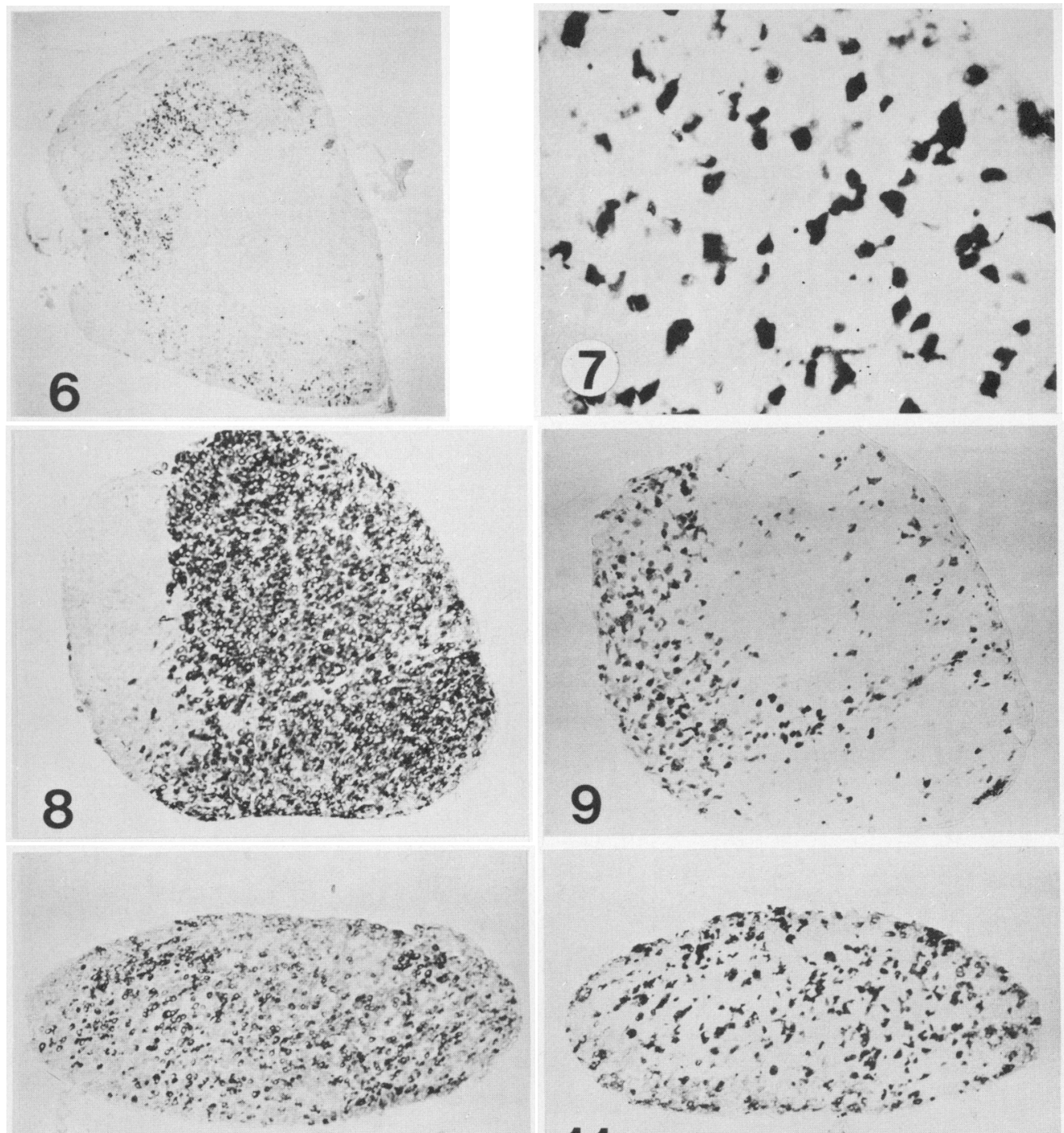

\section{0}

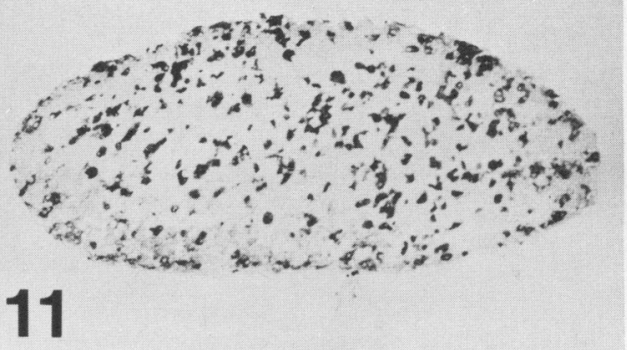

Fig. 6. Horizontal section of a pituitary gland from $M$. californicus collected in March (see text) immunostained with anti-rLTH serum. $\times 40$.

Fig. 7. Oblique sagittal section of the pars distalis from $M$. californicus collected in March (see text) immunostained with anti-rLH $\beta$ serum. $\times 360$.

Fig. 8. Coronal section of the pars distalis from $M$. californicus collected in June immunostained with anti-rLTH serum. $\times 88$.

Fig. 9. Coronal section from the same gland as in Fig. 8 immunostained with anti-rLH $\beta$ serum. $\times 88$.

Fig. 10. Oblique sagittal section of the pars distalis from $M$. californicus collected in August immunostained with anti-rLTH serum. $\times 88$.

Fig. 11. Oblique sagittal section from the same gland as in Fig. 10 immunostained with antirLH $\beta$ serum. $\times 88$. 
In March, the transition from delayed to 'normal' development began as signified by sudden enlargement of the pregnant horn of the bicornuate uterus. In animals collected in March, uterine horn dimensions were twice those of animals in the 3rd month of pregnancy, suggesting termination of delayed development. The pituitary then showed a marked increase in the number of immunoreactive prolactin cells (Pl. 1, Fig. 4), many of which were hypertrophied and ovoidshaped. Concomitantly, the density of cells staining with anti-LH $\beta$ remained the same as in November animals in early pregnancy (Pl. 1, Fig. 5), although the cells were even more pleomorphic.

Of special interest was another specimen, also collected in March, in which the uterine horn was 4 times larger than that of a bat in the 3rd month of pregnancy (a sign that 'normal' embryogenesis had begun) (P. H. Krutzsch, personal communication). The pars distalis showed a distinct decrease in the size of immunoreactive prolactin cells (PI. 2, Fig. 6) compared to the previous specimen. In addition, immunoreactive LH cells were fewer (Pl. 2, Fig. 7).

In animals which had recently given birth and were nursing, the cells stained with antiprolactin were increased in number and size (Pl. 2, Fig. 8), but LH cells decreased in number and size (Pl. 2, Fig. 9). When lactation subsided (August) and the ovary became gametic, immunoreactive prolactin cells were fewer (Pl. 2, Fig. 10), but many remained hypertrophied. The immunocytochemically identified LH cells, on the other hand, had begun to increase in number (Pl. 2, Fig. 11).

In addition to these cytological changes, the mean net weight of the pars distalis varied throughout the reproductive cycle (Text-fig. 1). A significant increase occurred just before parturition. Increases were also observed near mid-lactation and before the onset of 'normal' development, although the last were not statistically significant. These weight gains all coincided with observed increases in number and size of immunoreactive prolactin cells.

Thus, the populations and morphology of immunocytochemically identified prolactin and $\mathrm{LH}$ cells in the pars distalis of female Macrotus californicus vary in accord with the reproductive cycle. Prolactin cells diminish in size and number at the end of lactation, or near the onset of oestrus, then increase prior to the transition from delayed to 'normal' development. Concurrent with transition, a sudden decrease in cell size occurs. Before parturition these cells greatly increase in number and size and remain so until lactation ends in August or September. Increases in immunoreactive prolactin cell populations coincide with augmented weight of the pars distalis. Variations in immunoreactive LH cells are more subtle. The most obvious changes occur after ovulation, or early pregnancy, when size diminishes, and during lactation, when number and size decrease. There also appears to be a slight decrease in cell number and size at transition.

The above data implicate prolactin in delayed development. Whether it maintains the retarded state or initiates 'normal' development requires further study. Also, it is not known whether prolactin acts alone or in concert with another hormone or other hormones. Bleier (1975) observed that the corpus luteum acquires an active appearance at transition, and Burns \& Easley (1977) found an increase in plasma progesterone at the end of delayed development. Hence, prolactin may be luteotrophic and indirectly responsible for the onset of 'normal' development. The corpus luteum does not regress until well into lactation (P. H. Krutzsch, personal communication), which suggests that prolactin may play a luteal supportive role; by this time $\mathrm{LH}$ cells appear inactive.

Additional immunoperoxidase studies, ultrastructural observations and measurements of circulating plasma prolactin levels by radioimmunoassay are now in progress. These data will be correlated with the present results to clarify further the pituitary's role in delayed development in this unique reproductive model.

\section{Conclusions}

This review illustrates the need for continued research on the anterior pituitary and its role(s) in bat reproduction. In addition to a lack of information on the gland itself, there is an absence of 
studies utilizing modern and more direct means of measuring pituitary function (e.g. radioimmunoassay). As these techniques are refined and standardized, their applicability to the study of endocrine function of exotic species, such as bats, will increase.

Obviously, as in other mammals, the chiropteran pituitary serves as an intermediary between the brain (pineal and hypothalamus) and the target organs (testis and ovary). To gain better understanding of the interactions between reproduction and the environment and of the neuroendocrine mechanisms involved, attention must be directed towards the role of higher centres in bat reproduction. Only then will the unique reproductive specializations demonstrated by this interesting group of mammals be fully appreciated.

I am grateful to Dr P. H. Krutzsch and Dr B. Benson for their interest and encouragement in this research, to Dr J. B. Angevine for critically reviewing and to Miss Toni Foster for typing the manuscript. This work was supported, in part, by USPHS GRS Grant RR-05675.

\section{References}

Azzali, G. (1971) Citologia adenoipofisaria dei Chirotteri con particolare riguardo alle cellule $\mathrm{FSH}, \mathrm{LH}$, ACTH e LTH. Ateneo Parmense Sezione I, Acta biomed. 42, 169-229.

Baker, B.L. (1974) Functional cytology of the hypophysial pars distalis and pars intermedia. In Handbook of Physiology, Sect. 7, Vol. IV, Part 1, pp. 45-80. Eds. R. O. Greep \& E. B. Astwood. Am. Physiol. Soc., Washington, D.C.

Barrnett, R.J., Ladman, A.J., McAllaster, N.J. \& Siperstein, E.R. (1956) The localization of glycoprotein hormones in the anterior pituitary glands of rats investigated by differential protein solubilities, histological stains and bioassays. Endocrinology 59, $398-418$.

Bleier, W.J. (1975) Fine structure of implantation and the corpus luteum in the California leaf-nosed bat, Macrotus californicus. Ph.D. thesis, Texas Tech University, Lubbock, Texas.

Bradshaw, G.V.R. (1961) Le cycle de reproduction de Macrotus californicus (Chiroptera, Phyllostomatidae). Mammalia 25, 117-119.

Bradshaw, G.V.R. (1962) Reproductive cycle of the California leaf-nosed bat, Macrotus californicus. Science, N.Y. 136, 645-646.

Burns, J.M. \& Easley, R.G. (1977) Hormonal control of delayed development in the California leaf-nosed bat, Macrotus californicus. III. Changes in plasma progesterone during pregnancy. Gen. comp. Endocr. 32, $163-166$.

Burns, J.M. \& Wallace, W.E. (1975) Hormonal control of delayed development in Macrotus waterhousii. II. Radioimmunoassay of plasma estrone and estradiol $17-\beta$ during pregnancy. Gen. comp. Endocr. 25 , 529-533.

El Etreby, M.F. \& Fath El Bab, M.R. (1977) Localization of gonadotrophic hormones in the dog pituitary gland: a study using immunoenzyme histochemistry and chemical staining. Cell Tiss. Res. 183, 167-175.

Guthrie, M.J. (1935) The cytology of the ovaries and hypophysis of the bat, Myotis lucifugus lucifugus. Proc. I2th Int. Cong. Zool., Lisbon, pp. 359-360.
Guthrie, M.J. \& Jeffers, K.R. (1938) The ovaries of the bat Myotis lucifugus after injection of hypophyseal extract. Anat. Rec. 72, 11-36.

Herbert, D.C. (1975) Localization of antisera to LH $\beta$ and FSH $\beta$ in the rat pituitary gland. Am. J. Anat. 194, 379-385.

Herbert, D.C. (1976) Immunocytochemical evidence that luteinizing hormone $(\mathrm{LH})$ and follicle stimulating hormone (FSH) are present in the same cell type in the rhesus monkey pituitary gland. Endocrinology 98, 1554-1557.

Herlant, M. (1953) Étude comparative sur l'activité génitale des cheiroptères. Annls Soc. r. zool. Belg. 84, 87-116.

Herlant, M. (1956) Corrélations hypophyso-génitales chez la femelle de la chauve-souris Myotis myotis (Borkhausen). Archs Biol. 67, 89-180.

Herlant, M. (1962) Electron microscope studies on the adenohypophysis of Myotis myotis during gestation. Gen. comp. Endocr. 2, 631 .

Herlant, M. (1963) Apport de la microscopie électronique a l'étude du lobe antérieur de l'hypophyse. In Cytologie de l'Adenohypophyse, pp. 73-90. Eds J. Benoit \& C. Dalage. Éditions du Centre National de la Recherche Scientifique, Paris.

Herlant, M. (1964a) L'adeno-hypophyse de la chauvesouris, Myotis myotis au cours de la gestation. In Third European Regional Conference on Electron Microscopy, pp. 475-476. Ed. M. Titlbach. Academy of Sciences, Prague.

Herlant, M. (1964b) The cells of the adenohypophysis and their functional significance. Int. Rev. Cytol. 17, 299-382.

Herlant, M. (1967) Action de la gonadotropine FSH sur le tube seminifère de la chauve-souris hibernante. C. r. hebd. Séanc. Acad. Sci., Paris D 264, 24832486.

Herlant, M. (1968) Cycle sexuel chez les chiroptères des régions tempérées. In Cycles Genitaux Saisonniers de Mammifères, pp. 111-131. Ed. R. Canivenc. Masson et Cie, Paris.

Kobayashi, Y. (1966) The effect of hibernation upon the fine structure of the bat adenohypophysis. Fedn Proc. Fedn Am. Socs exp. Biol. 25, 536. 
Kobayashi, Y. \& Herman, L. (1966) Effect of hibernation upon the fine structure of the bat adenohypophysis. Proc. 6th Int. Congr. Electron Microscopy, Koyoto 2, 537-538.

Kurosumi, K. (1968) Functional classification of the cell types of the anterior pituitary gland accomplished by electron microscopy. Archum histol. jap. 29, 329362.

Moriarty, G.C. (1975) Electron microscopic-immunocytochemical studies of rat pituitary gonadotrophs: a sex difference in morphology and cytochemistry of LH cells. Endocrinology 97, 1215-1225.

Moriarty, G.C. (1976) Immunocytochemistry of the pituitary glycoprotein hormones. J. Histochem. Cytochem. 24, 846-863.

Moriarty, G.C. \& Garner, L.L. (1977) Immunocytochemical studies of cells in the rat adenohypophysis containing both ACTH and FSH. Nature, Lond. $265,356-358$.

Moudgal, N.R. (1973) The luteotropic action of luteinizing hormone. In The Regulation of Mammalian Reproduction, pp. 428-440. Eds S.J. Segal, R. Crozier, P. A. Corfman \& P. G. Condliffe. Charles C. Thomas, Springfield.

Nakane, P.K. (1970) Classification of the anterior pituitary cell types with immunoenzyme histochemistry. J. Histochem. Cytochem. 18, 9-20.

Patil, D.R. (1974) Comparison of pituitary gland cytology in three species of leaf-nosed bat (Hipposideridae). J. Anat. 118, 33-51.

Peyre, A. \& Herlant, M. (1963a) Correlations hypophyso-génitales chez la femelle du Minioptère (Miniopterus schreibersii B). Gen. comp. Endocr. 3, 726-727.

Peyre, A. \& Herlant, M. (1963b) Ovo-implantation différée et corrélations hypophyso-génitales chez la femelle du Minioptère (Miniopterus schreibersii B). C. r. hebd. Séanc. Acad. Sci., Paris D 257, 524526.

Purves, H.D. (1966) Cytology of the adenohypophysis. In The Pituitary Gland, Vol. 1, pp. 147-232. Eds G. W. Harris \& B.T. Donovan. University of California Press, Berkeley.

Racey, P.A. (1974) The reproductive cycle in male noctule bats, Nyctalus noctula. J. Reprod. Fert. 41, 169-182.

Racey, P.A. (1976) Induction of ovulation in the pipistrelle bat, Pipistrellus pipistrellus. J. Reprod. Fert. 46, 481-483.

Ramakrishna, P.A. \& Rao, K.V.B. (1977) Reproductive adaptations in the Indian Rhinolophid bat, Rhinolophus rouxi (Temminck). Curr. Sci. 46, 270271.
Ramaswami, L.S. \& Anand Kumar, T.C. (1966) Effect of exogenous hormones on the reproductive structures of the female bat Rhinopoma during the nonbreeding season. Acta anat. 63, 101-123.

Richardson, B.A. (1978) The pars distalis of the female California leaf-nosed bat, Macrotus californicus, and its possible role in delayed development. Anat. Rec. 190,521 .

Romeis, B. (1940) Innersekretorische Drüsen. II. Hypophyse. In Handbuch der Mikroskopischen Anatomie des Menschen, Vol. 6, Part 3, pp. 1-625. Ed. W. von Möllendorff, Springer, Berlin.

Sawyer, E. (1936) The cytology of the hypophysis cerebri of the bat. J. Morph. 50, 127-157.

Siegel, J.H. (1955) Cytochemical and histophysiological observations on the basophils of the anterior pituitary of the bat, Myotis lucifugus lucifugus. $J$. Morph. 96, 223-264.

Skreb, N. (1955) Influence des gonadotrophines sur les noctules (Nyctalus noctula) en hibernation. $C$. $r$. Séanc. Soc. Biol. 149, 71-74.

Sluiter, J.W., Bels, D.L. \& Van Oordt, G.J. (1952) The reproductive organs of female bats (Myotis myotis) following administration of large doses of gonadotrophins during the hibernation period. Acta endocr., Copenh. 9, 258-270.

Smith, E.W. (1951) Seasonal response of follicles in the ovaries of the bat Myotis grisescens to pregnancy urine gonadotrophin. Endocrinology 49, 67-72.

Steinberger, A. \& Steinberger, E. (1973) Hormonal control of mammalian spermatogenesis. In The Regulation of Mammalian Reproduction, pp. 139150. Eds S. J. Segal, R. Crozier, P. A. Corfman \& P. G. Condliffe. Charles C. Thomas, Springfield.

Sternberger, L.A., Hardy, Jr., P.H., Cuculis, J.J. \& Meyer, H.G. (1970) The unlabeled antibody enzyme method of immunohistochemistry: preparation and properties of soluble antigen-antibody complex (horseradish peroxidase-antihorseradish peroxidase) and its use in identification of spirochetes. $J$. Histochem. Cytochem. 18, 315-333.

Van Oordt, P.G.W.J. (1965) Nomenclature of the hormone-producing cells in the adenohypophysis. Gen. comp. Endocr. 5, 131-134.

Wimsatt, W.A. (1960) Some problems of reproduction in relation to hibernation in bats. Bull. Mus. comp. Zool. Harv. 124, 249-270.

Wimsatt, W.A. (1969) Some interrelations of reproduction and hibernation in mammals. Symp. Soc. exp. Biol. 23, 511-549.

Zondek, B. (1933) Action of folliculin and prolan on the reproductive organs of the bat during hibernation. Lancet ii, $1256-1257$. 